\title{
The Homer Multitext within the History of Access to Homeric Epic
}

\begin{abstract}
Through a series of descriptive vignettes, this paper considers "access" at selected points within the long history of the Homeric epics to investigate our own principles of access in the Homer Multitext. We examine modes of access to the Iliad and commentary on it in four historical eras (5th-century BCE Athens, 2nd-century BCE Alexandria, 1st-century CE Rome, and 15th-century CE Venice). Using the contexts of these historical moments, we then reflect on our own point in that history: how are we as editors replicating, replacing, or reviving modes or limitations of access through the structures and intentional editorial decisions of the digital Homer Multitext?
\end{abstract}

\section{Introduction}

The Homer Multitext (HMT) has its origins and purpose in the use of digital tools to better reveal, represent, and investigate the Homeric epics and their oral, traditional nature. Questions about the significance and consequence of access within the project arose as soon as we had acquired high-resolution digital photographs of three manuscripts of the Iliad from the Biblioteca Marciana in Venice (Marciana 821, 822, 841) in 2007. What do we mean by access, and what would access to these manuscripts look like within the HMT? What would it take to provide meaningful access to the texts they contain? Some of these questions were answered immediately and definitively: the Homer Multitext would publish those photographs under a Creative Commons license allowing for reuse by anyone even before we had used them in our own editions. As the team of HMT editors began work on creating digital editions from these and other manuscripts, we were confronted with further questions related to access: who is our intended audience or user, what will different users need from the editions, how will paradigms of scholarship shift now that access to the manuscripts will be more readily available and now that we can begin to ask questions about the texts and scholia that were simply not possible before?

These questions of access to the epic poetry - and to commentary on and interpretation of that poetry - have accompanied the Homeric epics through

Casey Dué, University of Houston

Mary Ebbott, College of the Holy Cross

Ә Open Access. (C) 2019 Casey Dué and Mary Ebbott, published by De Gruyter. (cc)BY-NC-ND This work is licensed under a Creative Commons Attribution-NonCommercial-NoDerivatives 4.0 International License. https://doi.org/10.1515/9783110599572-014 
much of their long history. After we look at selected points within that history and consider the shape of access at each one, we can ask how we are replicating, replacing, or reviving certain kinds of access through the digital medium and through the structures and intentional editorial decisions of the HMT. We have chosen four points in this long history to examine what access to the Iliad and commentary on it looked like, and each of them will provide some context and some questions to consider about our own point in that history.

\section{Athens in the late 5th century BCE}

It is a summer day. The moon is waning. It is the last week of Hekatombaion, and the annual festival of the Panathenaia is beginning. ${ }^{1}$ If it is the Great Panathenaia this year, celebrated every four years, there will be a weeklong series of events involving contests of both musical and athletic skills. The festival culminates in an elaborate procession in honor of Athena and the dedication of her new peplos. Then there will be a sacrifice of a hekatomb, one hundred cattle, providing a feast of meat for everyone there. On this first day of the festival, the musical competitions are held.

In a large performance space (venues throughout the centuries may have included the Agora, the Pnyx, the Odeon of Perikles, and much later the Theater of Dionysus), an international lineup of Homeric performers (rhapsodes) perform the epics of Homer, which have been strictly defined for this event as the Iliad and the Odyssey. The audience, numbering in the thousands, has access to these poems in performance, in a state-organized religious festival in honor of the patron goddess of the polis. The rhapsodes are competing for significant cash prizes, and they are held to specific rules. Each one must perform his assigned part, an episode between 500 and 800 lines long that is part of the defined narrative sequence. The rhapsode who performs the next episode in the sequence must be able to pick up the narrative thread where the last performer left off. Thus even as they compete with one another, the rules of the competition result in the rhapsodes connecting their performances to one another and cooperating to perform the complete narrative. This state-sanctioned and state-sponsored performance of the Homeric epics is its most authoritative in Athens.

Four years is a long time to wait for access to these poems again. It seems that the same rhapsodes who perform at the Panathenaia and other religious

1 For our description of the performance of the Iliad and Odyssey at the Panathenaia we are indebted to Connelly (2014), Nagy (2002), Neils (1992; 2007), and Shapiro (1992; 2015). 
festivals in other poleis can also offer a performance in the hopes of the audience paying them directly. Athenians might have access to the Homeric epics more often through a performance of that kind. Ion, the professional rhapsode in Plato's dialogue named for him, provides an example. ${ }^{2} \mathrm{He}$ has come to Athens for the Panathenaia having just competed in Epidauros (Ion 530a-b). Socrates expresses his hope that Ion will show him his skill in performing Homeric epic and in explaining it - that is, his expertise in being an interpreter of the poet's dianoia, or intention (530c-d). Thus rhapsodes in some situations provide commentary on the poetry as well. These other possible performances are implied when Socrates asks Ion about the emotional effects of his performance (535b-e). Ion agrees to Socrates' suggestion that a rhapsode would naturally pick either the exciting or the sad parts. The rhapsode selects which parts of the epics he wants to sing (or the audience might request a particular part), and he chooses the most emotionally affecting parts in order to get paid.

At the Panathenaia, the rules require that the whole song be sung in a particular order. When a rhapsode is performing on his own, the audience's preferences influence the choice of episodes and how they are performed. Such individual performances by rhapsodes, including explanation of the poetry, are also alluded to by the 4th-century Athenian orator Isocrates (Panathenaicus 18-19, 33), ${ }^{3}$ who disparages those who recite and explain Homeric epic in the Lyceum. What is the significance of this location for the performances that Isocrates criticizes? The Lyceum is a center of education, and men of a certain social class, at least, would have an education in which these epics held the greatest prominence. ${ }^{4}$ In two of Xenophon's dialogues about Socrates - his teacher as well as Plato's - an interlocutor is said to know or possess all of Homer's verses. In Xenophon's Symposium, Nikeratos relates “My father, taking care that I should become a good man, compelled me to learn all of Homer's verses. And now I could speak the whole Iliad and Odyssey 'by mouth' [i.e., 'by heart']." Euthydemos in the Memorabilia is asked by Socrates whether he wants to be a rhapsode, "for they say that you have acquired all of Homer's verses." 6 Euthydemos demurs, not, it seems, because he couldn't perform them, but

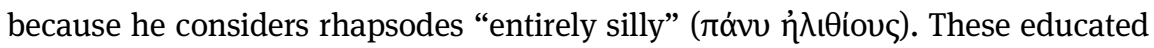

2 See Nagy $(1996$; 2002) for more on this dialogue and the performance of Homeric epic in the 5th century.

3 (Nagy 1996, 122-125).

4 See Robb (1994) and Yamagata (2012).

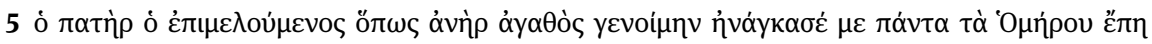

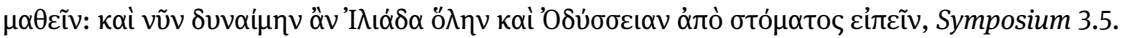

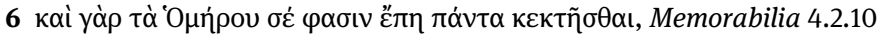


young men have been taught Homeric epic so thoroughly that each now seems to have access to any and all of it through his own memory. Their learning it by heart, so that it is something they "own", suggests that they can now access it without need for a text, if there ever was one.

In Classical Athens, Homeric epic was heard in many venues and situations, and these informal and formal performances provided access both to the poetry and to interpretation and thoughts about it. As we move ahead in time to the 2nd century BCE and to a different place - Alexandria, Egypt - we also shift to considering a proliferation of texts. Performance of the epics still occurred into the Roman era, but our next historical moment is focused on access to texts.

\section{Alexandria in the 2 nd century BCE}

Overlooking the city's great harbor on the Mediterranean is the famous Library of Alexandria, established by Ptolemy Soter, a promoter of scholarship. ${ }^{7}$ Its monumental collection grows each time a ship comes into that harbor: city officials collect whatever books are on board and bring them to the Library to be copied. The confiscated books are kept by the Library, and the copies returned to the owners, who had to hope they got a better deal in whatever business brought them to the city. What else might you expect from a Library with the purpose of collecting "all the books in world"?

Access to the Library's holdings might have been restricted to those scholars associated with the institution. (A smaller "sister" library, also founded by the Ptolemies, seems to have been available nearby and was more open.) Those privileged scholars in the famous Library might have been able to see hundreds of thousands of scrolls, rolled up with protective covers on, perhaps with a tag on the end to identify the contents. Under the Library directorship of Zenodotus in the 3rd century, Callimachus had created his Tables (Pinakes) that gave some account of the Library's holdings as representative of human knowledge: a collection of that size needs some way of being organized.

When it comes to the Iliad, collecting all the books in the world means collecting many copies, and as it happens, many versions of it. Three heads of the Library - Zenodotus of Ephesus [c. 284 - c. 260 BCE], Aristophanes of Byzantium [c. 194-180 BCE], and Aristarchus of Samothrace [sometime after

7 Our description of the Library and Egyptian papyri of the Iliad relies on Berti (2016), HellerRoazen (2002), Morgan (1998), Nagy (1996). See also Finkelberg (2006), McNamee (1981), and Porter (1992). 
180-145/4 BCE] - took advantage of the possibility afforded by the collection to compare these many versions. In the commentaries (hupomnemata) that Aristarchus wrote on the Iliad, he makes remarks and judgments on these many versions, which included the work of his predecessors in Alexandria and even scholars at other libraries, such as Crates at the rival library in Pergamum, as well as texts collected from several places around the Mediterranean, called in the scholia the "city" (politikai) copies. For scholars in a center of learning such as the Library of Alexandria at this time, access was abundant.

To judge by the number of papyri of the Iliad that survive from this period, the epic was also a popular text outside of the library. The general reader, whoever he may have been, had access to the Iliad in a common or standard version. As we move past the middle of the 2nd century, greater standardization is seen in the papyri. The texts found in the papyri are also simpler, usually without commentary or comparison to other texts, and are found throughout Egypt.

A subset of the papyri of the Iliad from this era have been identified as "school texts." Such papyri come from several locations in Egypt, including smaller towns and villages, and are a high proportion of papyri finds from the 2nd century BCE. To judge from the absolute number of these Homeric school texts found, the fact that they are about two-thirds of the total number found, and that the school texts of the Iliad far outnumber those of the Odyssey (86 vs 11), it seems that anyone who received some sort of education was introduced to the Iliad. Homeric epic was part of early education and continued to be central throughout formal education. This access may have been of a limited sort - for example, learning the first lines of the Iliad as a writing or memorization exercise - yet encounters with the Iliad in education were frequent.

From a beginning student learning to read and write to international scholars consulting texts from everywhere Homeric epic was known, a proliferation of texts in this period granted differing levels of access. The Iliad was both the foundation and the pinnacle of Greek learning. That status would continue under the Roman Empire.

\section{Rome in the 1st century CE}

An elaborate dinner party, one meant to impress, must offer entertainment as well as lavish food. The Iliad and Odyssey, now centerpieces of education for those classes distinguished by their learning in Greek, might show up in many forms: as subject matter for beautiful wall paintings within the dining room, as allusions embedded in dinner conversation between learned hosts and guests, 
or even more directly in performance, for at this dinner party the host has hired entertainers to act out episodes from the epics.

The dinner party that allows us this glimpse, albeit a satirical one, of the varieties of access to Homer in 1st-century CE Rome is the one given by the affluent and ostentatious freedman Trimalchio in Petronius' Satyricon. Trimalchio has wealth to match his limitless aspirations of status and esteem. ${ }^{8}$ But as Petronius portrays him, Trimalchio's former life has not prepared him for the life to which he aspires. While his guests are entertained by a group of Homeristai who act out episodes from the Homeric epics in Greek, Trimalchio reads along in a Latin crib.

The character of Trimalchio is being mocked for his intellectual pretensions and their attendant class aspirations: his attempts to display his own erudition is woefully confused, a hopeless jumble of half-remembered Greek myths. Trimalchio understands that among elite Romans "one ought to know philology even in the midst of dinner" (oportet etiam inter cenandum philologiam nosse 39), ${ }^{9}$ and he claims to possess libraries in both Latin and Greek (48), but he cannot understand the performance of the Homeristai without a Latin translation to guide him, and he mangles the plot of the Iliad when he speaks about it, indiscriminately mixing in an episode narrated in the Epic Cycle (and Greek tragedy), with dramatic culinary results.

By contrast we can assume that Petronius' learned audience does know their Homer, and so can understand just how much Trimalchio gets wrong. The Satyricon as a whole relies on its own audience's familiarity with the Iliad and Odyssey for its full effect of "playfulness and irony" with Homeric epic's grandeur. ${ }^{10}$ Trimalchio's feast, with its many Homeric allusions and in-jokes, reveals the various ways that Romans of different social classes might have encountered the Homeric poems in the Early Empire.

Most Romans probably did not experience Homer in books but in dramatic public performances in the tradition of mimes and pantomimes. In the Hellenistic world, and as early as the time of Demetrius of Phalerum in the late 4th century BCE, the performances of Homeric epic became more and more theatrical, performed at festivals along with mimes, pantomimes, and dances. ${ }^{11} \mathrm{By}$ the early Roman Empire, "Homeric performances had essentially become the

\footnotetext{
8 For the Homeric elements in the Satyricon, see Cameron (1969), Horsfall (1989), Farrell (2004), Hurka (2007), Schmeling (2002), and Ypsilanti (2010).

9 Or possibly, as Ruden translates it, "you've gotta know a little literature, even if it’s only for the dinner table."

10 (Ypsilanti 2010, 221).

11 (Nagy 1996, 153-186). See also González (2013, 447-465) with additional citations ad loc.
} 
prerogative of other Homerists - actors, mimes, and pantomimes, who came to be included in official performances and contests in the 2nd century CE, so popular had they become." 12 These more popular forms of Homeric entertainment are reflected in the performance of the Homeristai at Trimalchio's dinner when they act out battles scenes with shields and spears for the entertainment of Trimalchio's guests.

Trimalchio seems to think that he should know Homer if he is to impress high-class guests, even as his attempts to display his "philology" give his ignorance away. But why? The Romans connected their own foundational stories, their earliest history, to the Trojan War. ${ }^{13}$ By the 1st centuries BCE and CE frescoes in Roman houses depict Homeric landscapes and scenes: "elite Romans, like the Etruscans before them, surrounded themselves with visual Iliads and, especially, Odysseys."14 Roman letters from this time also display a deep familiarity with the poems on the part of educated Romans. Cicero, for example, not only quotes the epics but does so in playful ways that suggest intimate knowledge of them by both writer and audience. ${ }^{15}$

How did these elite Romans come by this familiarity? What did they have access to that a man like Trimalchio couldn't have? First and foremost was their education. As Farrell $(2004,267)$ describes it, "Easy familiarity with Homer was the mark of an expensive education." Children from wealthier Roman families were brought up with knowledge of Greek literature and especially Homer, as well as the Roman poets such as Livius Andronicus (who translated the Odyssey into Latin), Naevius, Ennius, and, later, Virgil. ${ }^{16}$ Horace attests to the Iliad's role in his education: Romae nutriri mihi contigit atque doceri/iratus Grais quantum nocuisset Achilles "It was my fate to be brought up in Rome and to be taught/ how much the angered Achilles harmed the Greeks," Epistles 2.2.41-42. If Trimalchio did not know Greek and therefore did not have "easy familiarity with Homer," he would always be out of place among the educated elite, no matter how much wealth he amassed.

What does access to Homer in written form look like at this point in time? How did a poet like Virgil, for example, come to know the Iliad and Odyssey so intimately? ${ }^{17}$ Given the limitations of our evidence, we have to essentially work

12 (Gangloff 2018, 147).

13 Joseph Farrell $(2004,254)$ has demonstrated that Homer pervaded Roman life, especially for elite Romans. See also Tolkhien $(1897,1900)$.

14 (Farrell 2004, 262).

15 (Farrell 2004, 266).

16 See Horace, Satires 1.6.71-78, Epistles 2.1.28-71 and 2.2.41-42, and Quintilian 1.8.5.

17 See Nelis (2010) for his exploration of this question. 
backwards, deducing what works Virgil must have consulted via the allusions we recognize to them, but we know little that is certain about his working methods. ${ }^{18}$ Libraries, both private and public, existed in and around Augustan Rome, though it is not clear who had borrowing privileges (if anyone did), or how easily texts were accessed. ${ }^{19}$ Cicero, for example, not only owned a great many books, he frequently borrowed books from his wealthy equestrian friend Atticus, who seems to have owned (or had access to) everything.

Both Virgil and Cicero came from families who could afford to provide them with an education. Virgil's patron, moreover, was Maecenas, and by extension, Augustus, putting him among "elite Romans," however elite is defined. Whether through personal collection, consultation of libraries, or borrowing from friends or literary patrons, Virgil had access to the Iliad and Odyssey, Greek tragedy, and the scholarly material that has been transmitted in the Homeric scholia. ${ }^{20}$ In addition to books, Virgil may have also had access to Homeric scholars. Aristonicus, whose work is excerpted in the scholia of the Venetus A manuscript of the Iliad, was in Rome during Virgil's lifetime and at least one point of contact can be found between Aristonicus' scholarly publications and Virgil's Aeneid. ${ }^{21}$

In Rome, the educated elite had easy access to Homer, even before the adoption of the codex book form or the establishment of public libraries at gymnasia or Trajan's grand public library, dedicated in 112/113 CE. ${ }^{22}$ Virgil could thus also expect his audience to be knowledgable about Homeric epic. They grew up surrounded by works of art depicting Homeric episodes that they could easily interpret, they learned vast stretches of the Iliad and Odyssey by heart in school, and they could buy, borrow, and consult texts of the poem on papyrus scrolls. Taking the fictional Trimalchio as a counterexample, we can surmise that non-elite Romans were not educated in the same way and that a lack of knowledge about Homeric epic marked their social status. On the other hand, they had a kind of access to the Iliad and Odyssey in the form of

18 For a similar approach to reconstructing the library of Plato, see Staikos (2013).

19 As Nicholas Horsfall $(2016,19)$ has observed, "Everything depended of course on who you were, and who your friends were." For the libraries attested in Virgil's lifetime, see the evidence compiled in Horsfall (2016, 28-29), as well as Horsfall (1993), Casson (2001, 61-123), Nelis (2010, 15-16), Bowie (2013), and Houston (2014). See also the other articles about libraries in the Roman Empire collected in König et al. (2013).

20 The scholarly literature on this topic is vast, but both Nelis (2010) and Horsfall (2016, 17-27) provide overviews with additional bibliography ad loc.

21 (Horsfall 2016, 23). On Virgil's access to and familiarity with Homeric scholarship see also Schlunk (1974).

22 On all three of these see Casson (2001, 80-108). 
various types of popular entertainment. As we move ahead a thousand years and more, access to texts remains a central question.

\section{Venice in the 15th century CE, by way of 10th century Byzantium}

As we look through the deluxe 10th-century manuscript of the Iliad, so full of writing on most of its pages, the unusual features stand out. The stain in the margin of one parchment folio perhaps made by red wine around the base of stemmed glass. Pages beautifully written in a 15th-century hand, five hundred years after the manuscript's construction, with empty margins. An invaluable but confusing set of front matter, rebound out of order. A set of 12th-century illustrations, including one that covers up some text. Anachronisms and anomalies like these in the Venetus A manuscript of the Iliad give us a glimpse into the Byzantine and Renaissance experience of accessing Homer in manuscript form.

Homer was transmitted from antiquity to the Middle Ages and beyond through the work of literary scholars and philosophers and through education. The Iliad and Odyssey remained the centerpieces of Greek education from Classical times through the Byzantine Empire. As Christianity developed, Homeric poetry was read through allegorical interpretation and continued to be important in the Christian Byzantine culture. Even beyond allegory, Homer was cited as an authority alongside scripture in both secular and Christian rhetoric. ${ }^{23}$

The Romans who read Homer during imperial times would have done so on papyrus scrolls. Eventually, parchment codices, which resemble modern books in their shape and construction, superseded scrolls as the medium for transmitting literature. ${ }^{24}$ Alexandrian and Roman scholars had published their scholarly works and commentaries on the poems in separate scrolls, which could be keyed to the Homeric texts by means of critical signs. ${ }^{25}$ The earliest surviving manuscripts of the Iliad and Odyssey contain both the texts of the poems themselves and excerpts from the scholarly commentaries of antiquity, copied into their margins. These writings in the margins, known as scholia, explain points of grammar, usage, the meaning of words, interpretation of the poetry, and arguments about the correct text and the authenticity of verses. Only a small number of the nearly 200 medieval manuscripts of the Iliad are deluxe editions complete with scholia.

23 (Browning 1992).

24 (Casson 2001, 124-135); (Ebbott 2009); (Reynolds and Wilson 2014, 34-36).

25 (Pfeiffer 1968, 218); (Nagy 2004, 33-34); (Bird 2009); (Schironi 2018 and forthcoming). 
Who had access to such deluxe editions? Who purchased them, read them, and benefitted from their learned commentaries? For whom was the Venetus A, so lavishly produced, initially made? We simply do not know. While we can learn much about how this manuscript was constructed from the document itself, ${ }^{26}$ we don't know anything about who commissioned or originally owned this artifact. But its contents reveal that this was no school text, nor was it meant for a casual reader. Not only are difficult points of grammar and punctuation and obscure vocabulary discussed throughout, but the work of the Alexandrian editors who were attempting to establish the correct text of the poem is quoted and discussed extensively. In assembling so much learned commentary into a single document, the Venetus A becomes itself a work of scholarship.

We do know something about a later owner, the Greek Cardinal Basileus Bessarion. He acquired both the Venetus A and the Venetus B (an 11th-century manuscript, also in Venice's Marciana Library) in the 15th century CE and donated them together with his entire collection of Greek manuscripts to the Republic of Venice, thereby forming the Marciana library's initial collection. ${ }^{27}$ Basileus Bessarion began collecting books at a very early age, and initially on a very constrained budget, when he was a student of philosophy in the Byzantine city of Mistra, in the Peloponnese. As his career in the church advanced, his ability to acquire manuscripts increased, and so did his desire to amass a great library. In 1437 the Byzantine Emperor John VIII Philologus made him Metropolitan of Nicaea and dispatched him to Italy to participate in the decades-long negotiations between the Western and Eastern churches. These negotiations brought Bessarion to the city of Venice in 1438. This Serenissima Repubblica di Venezia came to represent for Bessarion a hope for a "Second Byzantium."

Over the next decades, Bessarion's efforts toward building an allencompassing library of Greek learning took on a new urgency. When news of the fall of Constantinople came to Italy, Bessarion wrote to Michael Apostolis, from whom he had already borrowed, bought, and copied a great number of books, including works on Homeric epic by Quintus of Smyrna. Formerly, he said to his friend, he had collected books for his own pleasure. Now that Constantinople was in the hands of the Ottoman Sultan, he wanted to acquire all Greek literature, to keep it in some safe place, where it would be accessible to all readers until Greece was once again free.

26 (Allen 1899); (Dué 2009); (Dué and Ebbott 2014); (Kalavrezou 2009).

27 For more on Bessarion and the historical context in which he acquired and then donated the Venetus A to the Republic of Venice, see Blackwell and Dué (2009), as well as Labowski (1979). 
Is the wine glass stain in the Venetus A Bessarion's? There is probably no way to know. But it is quite possible that the nineteen folios of the Venetus A that are written in a 15th century hand, folios that no doubt were lost from the original manuscript during the centuries between its construction and Bessarion's acquisition of it and had to be replaced, are the work of Bessarion's own hand. Because the parchment used was so durable, manuscripts were typically rebound and repaired at many points in their history. It is possible that during the rebinding of the Venetus A required to add Bessarion's replacement folios, some of the front matter (which preserves excerpts from Proclus' Chrestomathy, including a summary of most of the now lost poems of the Epic Cycle) was rebound out of order.

Three centuries earlier, an owner of the Venetus A copied an excerpt from Heliodorus' novel, the Aithiopika, into a blank portion of a folio in the front matter, perhaps confusing the Aithiopika with the similarly titled epic poem the Aithiopis. Soon after (within a century) someone had painted over it and also added to the margins in the front matter illustrations of scenes from the Epic Cycle. As manuscripts changed owners through the centuries and went through varying periods of neglect and care, and as the needs and desires of readers evolved, manuscripts of the Iliad and Odyssey both gained and lost valuable material.

When Bessarion donated his manuscript collection to the Republic of Venice in 1468, his collection became a public library that offered access to the works of philosophers, scientists, and theologians, and that was responsible for the rediscovery in Europe of such authors as Athenaeus and Ptolemy the Geographer. Nowhere is the depth and significance of Bessarion's gift more apparent than in his donation of two complete manuscripts of the Homeric Iliad. These are now known from their catalogue entries in the Marciana library as Marciana 822 [= Marcianus Graecus Z. 454], the Venetus A, and Marciana 821 [= Marcianus Graecus Z. 453], the Venetus B. Both contain the text of the Iliad, surrounded by scholia, which preserve the research and editorial work of the scholars of Ptolemaic Alexandria and Rome. These two manuscripts are now at the heart of the Homer Multitext, a project that provides access to the Homeric epics, Homeric scholarship, and the historical artifacts that transmit them in digital form.

\section{Access in the 21st century - location unrestricted}

Bessarion's gift of the Venetus A and B manuscripts of the Iliad to the Republic of Venice has given us access to the Homeric scholarship of antiquity. If not for its preservation in the margins of these manuscript, much of that scholarship would be lost. Through access to that scholarship we can better reconstruct 
Archaic performance traditions, the editorial practices of Hellenistic and Roman scholars, and the centrality of the Homeric epics in Greek education across the centuries.

In the centuries that followed Bessarion's donation, new technologies allowed for new means of access to the Iliad. ${ }^{28}$ The first printed edition of the Greek text of the Iliad (without scholia) was made in Florence in 1488-1489. The Venetus A and B manuscripts of the Iliad were not published until 1788, when Jean Baptiste d'Anse de Villoison rediscovered them, so to speak, in the Marciana Library in Venice and published an edition of the Iliad, drawing on the texts of both manuscripts, and included their scholia in the back of the book. Prior to that time, they remained in keeping, publicly available, but not, apparently, accessed. ${ }^{29}$ In 1901, a photographic facsimile of the Venetus A by Domenico Comparetti was published, allowing a new kind of access to the manuscript outside of the Marciana library. Other editions of the epic poem and other editions of the scholia (always separate from one another) were produced in the 19th and 20th century.

How does the Homer Multitext fit into this long history of the Iliad and the commentary on it? What can we learn from these other eras as we continue to think intentionally about what we want access to mean in this digital age? Will digital editions like the Homer Multitext replace print editions, and what would it mean to do so? First we should note that this history shows us that different technologies - access afforded by oral performance vs. written text, scrolls vs. codices, manuscripts vs. printed books - overlap for a long time before one ever replaces the other completely, if that ever happens. Perhaps, then, we should consider how digital media allow us to revive the manuscripts and make them more accessible, rather than simply replace the print edition. What else is worth reviving from this long history? What do we want to replicate from the past, and what do we want to avoid replicating?

Picture the audience of thousands at the Panathenaia listening to the performance of the Iliad. Scale of access is one element in our decision making: how to give the greatest number of people access. Those thousands in Athens were all experiencing that performance at the same time in the same space.

\footnotetext{
28 (Ebbott 2009).
}

29 This is not to say that they were never accessed, just that they were not widely known. The scholar Martino Filetico evidently consulted them while they were still in there possession of Bessarion, and about a century later the Venetian scholar Vettore Fausto transcribed the Venetus A's scholia and critical signs for books 19-22 of the Iliad into his own copy of the 1488 editio princeps of the Iliad, now Marcianus Graecus IX 35. (On these early consultations see Pontani's (2001) review of Pincelli (2000) as well as Erbse (1969, xv-xvi).) 
Digital technologies can also create large-scale access, without limitations by time or space. Bessarion wanted to preserve manuscripts and the learning they contained, and so he moved them out of Byzantium and provided the beginning of a public library. If the digital photographs of those manuscripts he donated are likewise going to help preserve their contents for further generations to access, our policy that allows duplication and distribution uncontrolled by the HMT is one way of enabling such preservation. Yet we must also be attentive to the rapid obsolescence of digital technologies. The Venetus A parchment codex continues to survive after a thousand years - what can and must we do to ensure that those photographs and our digital editions will be accessible in another decade, let alone in another millennium?

Now recall the multitude of texts of the Iliad that the Library of Alexandria gathered in its quest to collect all the books in the world. At that point in history, a select few had access to a great number of witnesses to the epic, and they were able to create editions and commentary from sources that no longer survive. The HMT seeks to replicate the multiplicity of that collection and the comparison of complete witnesses that the Library enabled. (Recall that Bessarion, too, acquired more than one version of the Iliad with scholia for his collection.) Although we cannot recover all of what the Alexandrian scholars had access to, by publishing our manuscripts as we have, with no fees and under a Creative Commons 4.0 non-commercial-attribution-share alike license, we can give access to the surviving information and revive complete versions of the scholia, at least.

At the same time, we seek to replace the model in which only a privileged few have access to the manuscripts. One profound shift that has already been realized by the digital access to the manuscripts is the involvement of undergraduates in the creation of the digital editions, together with new kinds of research that those digital editions make possible. Even in our own lifetimes, consulting manuscripts and being a textual editor were activities reserved for only a rare few: the rest of us had to rely on their editions. In the past decade, more than 100 undergraduate students have contributed to the creation of a complete digital edition of the Venetus A manuscript. With many more manuscripts, papyri, and other sources to be added, that number will continue to grow. Through the published digital photographs of the Venetus A manuscript, one of our summer undergraduate researchers, working for 40 hours per week for 9 weeks, has spent more time closely examining the texts it contains, on its very pages, than anyone had access to for centuries. We have seen that undergraduates from a range of institutions in the United States and the Netherlands are more than capable of reading the minuscule and semiuncial scripts, deciphering the ligatures and also the dense expression of the scholia, applying structured markup to defined elements of the contents, and formulating and pursuing creative 
research that emerges from their intense familiarity with the manuscript - both its contents and its physical form and layout. ${ }^{30}$ Greater access has thus already changed the "received wisdom" of who can read manuscripts and who can contribute to our understanding of the textual history of the epics.

Another practice of past access that we want to replace: the edition of the Iliad that seeks to reconstruct an hypothesized "original”. We seek to supersede that approach with a clear picture of the multiformity with which the Iliad has been transmitted to us. The Homer Multitext allows each surviving document to be viewed and considered on its own terms. Our recently completed digital edition of the text and scholia of the Venetus A manuscript of the Iliad provides a complete transcription of every page of the manuscript, spatially linked to the already published high-resolution images. The transcriptions are encoded in XML and are freely available in both human- and machine-readable form via the HMT. Digital tools, some already available and some still in development, allow users to interact with and search the text in a variety of ways. This fundamental editorial decision, to represent each historical instantiation of the Iliad as a whole worthy of study (alone and in comparison with other historical instantiations), is one that we arrived at over the course of many years of experimentation, theorizing, and reflection. In the end we concluded that proceeding in this way is the only way to accurately represent the history and transmission of a poem composed in performance. We do not want to replicate the mistakes of scholars over the millennia who have sought in vain to recover a single authoritative text from an oral tradition in which, to paraphrase Albert Lord, there was quite simply no original to be found. ${ }^{31}$

We have also decided not to simply replicate the practice of the apparatus criticus, and that decision also has a basis in considerations of access. We have argued elsewhere the problems inherent in a typical apparatus. ${ }^{32}$ To be blunt, the conventional apparatus is a barrier rather than a means to access (and to be even blunter, some people seem to like that about it). Only the most specialized consulters of an apparatus criticus can decode what it is attempting to convey, and even they will be often at a loss as to what the original sources actually say. There are types of information, such as how the layout of the page creates relationships between texts, that an apparatus simply cannot convey. Digital

30 For just two examples, see Blackwell et al. (2016), and Churik and Smith (forthcoming). For more examples, see the posts on the Homer Multitext blog with the label "undergraduate research": http://homermultitext.blogspot.com/search/label/undergraduate research (last access 2019.01.31).

31 (Lord 1960, 100-101).

32 See, e.g., Dué and Ebbott (2009; 2010, 153-159; 2016). 
tools of textual analysis, developed for texts in many languages across many formats of publication, also make the conventional apparatus obsolete.

There are many questions remaining about future developments of the project. How will a user of the Homer Multitext make comparisons between readings? In fact, during this phase of the project we have chosen not to worry excessively about how precisely our data will be used to make such comparisons. Instead, we have forefronted our efforts not to replicate the contempt aimed at Trimalchio by those who knew their Homer "better" than he did. A related question about access that we continue to confront is the role of translation of the texts (whether the poetry or the scholia), or what kinds of other contextual information are necessary to aid nonspecialists in their navigation of the texts. As our digital editions are published, what will we need to add to increase access and invite more researchers and readers into the study of the epics? On a conceptual level, the editors of the Homer Multitext have concluded that making the evidence of the historical sources available to every individual reader, thereby allowing them the tools to understand and even make editorial judgements for themselves, is the kind of access we want to provide. It is time, and now possible, to reach new audiences and ask new questions.

\section{Bibliography}

Allen, T. (1899): “On the Composition of Some Greek Manuscripts: The Venetian Homer”. Journal of Philology 26, 161-181.

Berti, M. (2016): “Greek and Roman Libraries in the Hellenistic Age”. In: S. White Crawford; C. Wassen (eds.): The Dead Sea Scrolls at Qumran and the Concept of a Library. Studies in the Documents of the Judean Desert Series. Leiden and Boston: Brill, 31-54.

Bird, G. (2009): “Critical Signs - Drawing Attention to 'Special' Lines of Homer's Iliad in the Manuscript Venetus A”. In: C. Dué (ed.): Recapturing a Homeric Legacy: Images and Insights from the Venetus A Manuscript of the lliad. Cambridge, MA: Harvard University Press, 89-115.

Blackwell, C.; Dué, C. (2009): “Homer and History in the Venetus A". In: C. Dué (ed.): Recapturing a Homeric Legacy: Images and Insights from the Venetus A Manuscript of the Iliad. Cambridge, MA: Harvard University Press, 1-18.

Blackwell, C.; Roughan, C.; Smith, D. (2016): “Citation and Alignment: Scholarship Outside and Inside the Codex". Manuscript Studies 1, 5-27.

Bowie, E. (2013): “Libraries for the Caesars”. In: K. König; K. Oikonomopoulou; G. Woolf (eds.): Ancient Libraries. Cambridge: Cambridge University Press, 237-260.

Browning, R. (1992): “The Byzantines and Homer”. In: R. Lamberton; J. Keaney (eds.): Homer’s Ancient Readers. Princeton: Princeton University Press, 134-148.

Cameron, H. (1969): “The Sybil in the Satyricon". Classical Journal 65, 337-339.

Casson, L. (2001): Libraries in the Ancient World. New Haven: Yale University Press. 
Churik, N.; Smith, D. (forthcoming): “Design and Layout of the Richest Manuscript of the Iliad". Anvil Academic. http://anvilacademic.org/projects/d-neel-smith-and-nikolaschurik-design-and-layout-of-the-richest-manuscript-of-the-iliad/ (last access 2019.01.31).

Comparetti, D. (ed.) (1901): Homeri Ilias cum scholiis. Codex venetus A, Marcianus 454 phototypice editus. Leiden: Sijthoff.

Connelly, J.B. (2014): The Parthenon Enigma. New York: Vintage Books.

Dué, C. (ed.) (2009): Recapturing a Homeric Legacy: Images and Insights from the Venetus A Manuscript of the Iliad. Cambridge, MA: Harvard University Press.

Dué, C.; Ebbott, M. (2009): “Digital Criticism: Editorial Standards for the Homer Multitext”. Digital Humanities Quarterly 3: 1. http://www.digitalhumanities.org/dhq/vol/003/1/ 000029/000029.html (last access 2019.01.31).

Dué, C.; Ebbott, M. (2010): Iliad 10 and the Poetics of Ambush: A Multitext Edition with Essays and Commentary. Cambridge, MA, and Washington, DC: Center for Hellenic Studies.

Dué, C.; Ebbott, M. (2014): “An Introduction to the Homer Multitext Edition of the Venetus A manuscript of the Iliad". The Homer Multitext. http://www.homermultitext.org/manu scripts-papyri/VenA-Introduction-2014.html (last access 2019.01.31).

Dué, C.; Ebbott, M. (2016): “The Homer Multitext and the System of Homeric Epic”. Classics@ 14. https://chs.harvard.edu/CHS/article/display/6524 (last access 2019.01.31).

Ebbott, M. (2009): “Text and Technologies: The lliad and the Venetus A". In C. Dué (ed.): Recapturing a Homeric Legacy: Images and Insights from the Venetus A Manuscript of the Iliad. Cambridge, MA: Harvard University Press, 31-56.

Erbse, H. (ed.) (1969-1988): Scholia Graeca in Homeri Iliadem (scholia vetera). 7 Vols. Berlin: De Gruyter.

Farrell, J. (2004): “Roman Homer”. In: R. Fowler (ed.): The Cambridge Companion to Homer. Cambridge: Cambridge University Press, 254-271.

Finkelberg, M. (2006): "Regional Texts and the Circulation of Books: The Case of Homer". Greek, Roman, and Byzantine Studies 46, 231-248.

Gangloff, A. (2018): “Rhapsodes and Rhapsodic Contests in the Imperial Period”. In: J. Ready; C. Tsagalis (eds.) (2018): Homer in Performance: Rhapsodes, Narrators, and Characters. Austin: University of Texas Press, 130-150.

González, J. (2013): The Epic Rhapsode and His Craft: Homeric Performance in a Diachronic Perspective. Washington, DC: Center for Hellenic Studies.

Heller-Roazen, D. (2002): “Tradition's Destruction: On the Library of Alexandria”. October 100, 133-153.

Horsfall, N. (1989): ““The Uses of Literacy' and the 'Cena Trimalchionis': I”. Greece \& Rome 36, 74-89.

Horsfall, N. (1993): "Empty Shelves on the Palatine”. Greece \& Rome 40, 58-67.

Horsfall, N. (2016): The Epic Distilled: Studies in the Composition of the Aeneid. Oxford: Oxford University Press.

Houston, G. (2014): Inside Roman Libraries: Book Collections and their Management in Antiquity. Chapel Hill, NC: The University of North Carolina Press.

Hurka, F. (2007): “Die literarisch gebildeten literarischen Barbareien des Trimalchio”. In: L. Castagna; E. Lefèvre (eds.): Studien zu Petron und seiner Rezeption. Berlin and New York: De Gruyter, 213-225.

Kalavrezou, I. (2009): “The Twelfth-Century Illustrations in the Venetus A". In: C. Dué: Recapturing a Homeric Legacy: Images and Insights from the Venetus A Manuscript of the Iliad. Cambridge, MA: Harvard University Press, 117-132. 
König, J.; Oikonomopoulou, K.; Woolf, G. (eds.) (2013): Ancient Libraries. Cambridge: Cambridge University Press.

Labowsky, L. (1979): Bessarion's Library and the Biblioteca Marciana: Six Early Inventories. Sussidi Eruditi 31. Roma: Edizioni di storia e letteratura.

Lord, A. (1960): The Singer of Tales. Cambridge, MA: Harvard University Press.

McNamee, K. (1981): “Aristarchus and 'Everyman's' Homer”. Greek, Roman, and Byzantine Studies 22:3, 247-255.

Morgan, T. (1998): Literate Education in the Hellenistic and Roman Worlds. Cambridge: Cambridge University Press.

Nagy, G. (1996): Poetry as Performance: Homer and Beyond. Cambridge, MA: Harvard University Press.

Nagy, G. (2002): Plato's Rhapsody and Homer's Music: The Poetics of the Panathenaic Festival in Classical Athens. Washington, DC: Center for Hellenic Studies.

Nagy, G. (2004): Homer's Text and Language. Urbana and Chicago, IL: University of Illinois Press.

Neils, J. (ed.) (1992): Goddess and Polis: The Panathenaic Festival in Ancient Athens. Hanover, NH and Princeton, NJ: Princeton University Press.

Neils, J. (2007): "Replicating Tradition: The first celebrations of the Greater Panathenaia". In: O. Palagia; A. Choremi-Spetsieri (eds.): The Panathenaic Games. Oxford: Oxbow Books, 41-51.

Neils, J. (ed.) (2015): Worshipping Athena: Panthenaia and Parthenon. Madison, WI: University of Wisconsin Press.

Nelis, D. (2010): “Vergil’s Library”. In: J. Farrell; M. Putnam (eds.): A Companion to Vergil’s Aeneid and its Tradition. Malden and Oxford: Wiley-Blackwell, 13-25.

Pfeiffer, R. (1968): A History of Classical Scholarship: From the Beginnings to the End of the Hellenistic Age. Oxford: Oxford University Press.

Pincelli, M. (ed.) (2000): Martini Philetici In corruptores Latinitatis. Roma: Edizioni di storia e letteratura.

Pontani, F. (2001): Review of M. Pincelli, Martini Philetici In corruptores Latinitatis (Rome, 2000). Bryn Mawr Classical Review 2001. 03.22.

Porter, J. (1992): "Hermeneutic Lines and Circles: Aristarchus and Crates on the Exegesis of Homer”. In: R. Lamberton; J. Keaney (eds.): Homer's Ancient Readers. Princeton: Princeton University Press, 67-114.

Reynolds, L.; Wilson, N. (2014): Scribes and Scholars: A Guide to the Transmission of Greek \& Latin Literature. 4th ed. Oxford: Oxford University Press.

Robb, K. (1994): Literacy and Paideia in Ancient Greece. Oxford: Oxford University Press.

Ruden, S. (2000): Petronius/Satyricon. Indianapolis, IN: Hackett Publishing.

Schironi, F. (2018): The Best of the Grammarians: Aristarchus of Samothrace on the lliad. Ann Arbor, MI: University of Michigan Press.

Schironi, F. (forthcoming): “Early Editions”. In: C. Pache (ed.): Cambridge Homer Encyclopedia. Cambridge: Cambridge University Press.

Schlunk, R. (1974): The Homeric Scholia and the Aeneid: A Study of the Influence of Ancient Homeric Literary Criticism on Vergil. Ann Arbor, MI: University of Michigan Press.

Schmeling, G. (2002): “(Mis)uses of Mythology in Petronius”. In: J.F. Miller; C. Damon; K.S. Myers (eds.): Vertís in Usum: Studies in Honor of Edward Courtney. München and Leipzig: K.G. Saur, 152-163. 
Shapiro, H. (1992): “Mousikoi Agones: Music and Poetry at the Panathenaia”. In: J. Neils (ed.): Goddess and Polis: The Panathenaic Festival in Ancient Athens. Hanover, NH and Princeton, NJ: Princeton University Press, 53-76.

Shapiro, H. (2015): "Democracy and Imperialism: The Panathenaia in the Age of Perikles". In: J. Neils (ed.): Worshipping Athena: Panathenaia and Parthenon. Madison, WI: University of Wisconsin Press, 215-225.

Staikos, K. (2013): Books and Ideas: The Library of Plato and the Academy. trans. N. Koutras. New Castle, DE: Oak Knoll Press.

Tolkhien, J. (1897): De Homeri auctoritate in cotidiana Romanorum vita. Jahrbücher für classiche Philologie Suppl. 23. Leipzig.

Tolkhien, J. (1900): Homer und die römische Poesie. Leipzig: T. Weicher.

Yamagata, N. (2012): "Use of Homeric References in Plato and Xenophon." Classical Quarterly 62:1, 130-144.

Ypsilanti, M. (2010): “Trimalchio and Fortunata as Zeus and Hera: Quarrel in the 'Cena' and 'Iliad”.' Harvard Studies in Classical Philology 105, 221-237. 